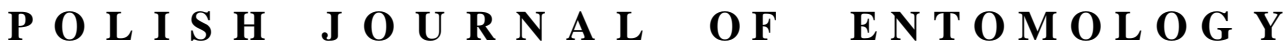

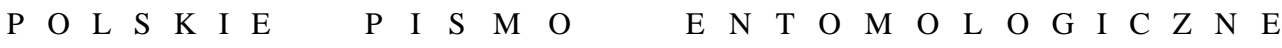

VOL. 85: 121-133

Lublin

30 March 2016

DOI: $10.1515 /$ pjen-2016-0006

\section{Field assessment of the susceptibility of onion cultivars to thrips attack - preliminary results}

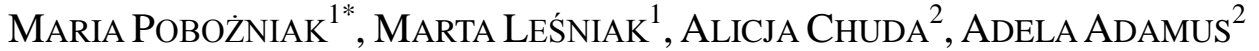 \\ ${ }^{1}$ Department of Plant Protection, Faculty of Biotechnology and Horticulture, University \\ of Agriculture, al. 29 Listopada 54, 31-425 Kraków, Poland \\ ${ }^{2}$ Institute of Plant Biology and Biotechnology, Faculty of Biotechnology and Horticulture, \\ University of Agriculture, al. 29 Listopada 54, 31-425 Kraków, Poland
}

\begin{abstract}
Field experiments on the susceptibility of onion to thrips infestation were carried out in 2012 and 2013. The investigation used 18 cultivars and 5 breeding lines of Allium cepa, and the species A. fistulosum and A. roylei. In 2012 A. fistulosum was one of the most infested plants, whereas in 2013 infestation was no more than average. The most infested cultivars of A. cepa were 'Efekt', 'Alonso F1', 'Alibaba' and 'Wama' and the 'NOE5' breeding line. In 2012 the extent of damage ranged from 12 to $55 \%$, in 2013 from 20 to 30\%. The 'NOE2', 'NOE3' and 'Wama' cultivars were the most seriously damaged by thrips. Leaf damage to A. fistulosum was minimal. No damage was caused to the wild species $A$. roylei by feeding onion thrips.
\end{abstract}

KEY WORDS: Onion thrips Allium sp., resistance, damage .

\section{INTRODUCTION}

Onions are grown in Poland over a fairly large area. They are the third most commonly cultivated field vegetable in the country, making up approximately $16.2 \%$ of the vegetables grown there. Nonetheless, its production has further increased and currently amounts to approximately 670 thousand tonnes per year, putting Poland in third place in Europe after Spain (1.1 million tonnes) and the Netherlands (883 thousand tonnes) (CSoP 2012).

\footnotetext{
*Corresponding author: maria.pobozniak@gmail.com
} 
Thrips tabaci LIMDEMAN, 1889 is an onion pest that occurs in most areas of onion production globally and is of economic importance (LEWIS 1973). It has been recorded on plants from 29 families (RASPUDIĆ \& IVEZIĆ 1999) and in Europe, Africa and in other continents is regarded as a pest of onion, leek and cabbage (DIAZ-MONTANO et al. 2010, GombaČ \& TRDAN 2014, Liu \& SPARKs 2003, Maniania et al. 2003, PÉnZES et al. 1996, TRDAN 2003). T. tabaci causes significant economic losses in that it Can reduce yields by up to $60 \%$ (WAIGANJO et al. 2008).

Feeding on onions, thrips and their larvae usually select young, delicate leaves. They damage the tissue and suck the sap from the leaves, causing silvery spots, which enlarge with increasing foraging intensity (KeNDALL \& CAPINERA 1990, PARRELLA \& LEWIS 1997). This damage can lead to the deformation, breaking and desiccation of stems, which leads to significant reductions in yields (LEWIS 1997, LEVY \& KEDAR 1970). The scale of the injuries caused by Thrips tabaci depends on the region, the local conditions and the method of cultivation, as well as the developmental phase of the crop and the plant variety (COUdRIET et al. 1979, FourniER et al. 1995, DiAZ-Montano et al. 2012, HudÁK \& PÉNZES 2004, Kendall \& CAPINERA 1987). In their pursuit of the highest yield, developers of new cultivars often fail to take susceptibility to pests into account. According to SMITH (2005), the pest population density can be significantly reduced by growing pestresistant varieties. The cultivation of such varieties can reduce the average level of the pest population below the harmfulness threshold, thereby reducing the number of chemical treatments required and the overall cost of production (METCALF \& LUCKMANN 1975). According to KogAn (1975) and SMITH (2005), plant resistance depends on the physical and chemical properties of different cultivars. In order to obtain resistant plant cultivars, sources of resistance are sought from both old and new cultivars, as well as wild species.

The aim of this study was to compare the susceptibility to thrips colonization and feeding of different cultivars and breeding lines, namely, the cultivated species Allium cepa LINNAEUS, 1753 and A. fistulosum LinNAEUS, 1753, and the wild species A. roylei STEARN, 1947.

\section{MATERIAL AND METHODS}

Field experiments on the susceptibility of onions to thrips colonization were carried out in 2012 and 2013 at the Experimental Station of the Faculty of Biotechnology and Horticulture, Kraków Agricultural University, situated in Mydlniki (near Kraków, southern Poland $50^{\circ} 04^{\prime} \mathrm{N}, 19^{\circ} 51^{\prime} \mathrm{E}, 207 \mathrm{~m}$ amsl). The investigation used 18 cultivars (commercial seeds) and 5 breeding lines (seeds from Spójnia Hodowla i Nasiennictwo Ogrodnicze sp. $\mathrm{z}$ o.o. in Nochowo) of onion (Allium cepa), as well as the species Allium fistulosum 
(commercial seeds) and Allium roylei (seeds from gene bank). The surveys were carried out from 17 June to 23 August 2012, and from 19 June to 28 August 2013. In both years onion seeds were sown in early April, on $3 \times 4 \mathrm{~m}\left(12 \mathrm{~m}^{2}\right)$ plots. In 2012, it was not possible to perform the survey on A. roylei owing to its very poor emergence. Throughout the studies on the experimental plots no chemical treatments were employed, and weeds were removed by hand.

The susceptibility of the test species, cultivars and breeding lines of onion to thrips colonization was determined from the number of pests caught using standard entomological sweep nets and specimens collected from 10 randomly selected plants. Each individual sampling event consisted of 25 sweeps with the nets in a single test plot. Sweeps were carried out in the afternoon hours of a sunny day throughout the growing season at intervals of around two weeks: POBOŻNIAK \& KOSCHIER (2013) reported that the highest activity of Thrips tabaci occurs at this time. The material collected was preserved in ethanol and microscope slides were prepared according to the methodology specified by ZAWIRSKA (1994). Taxonomic identification was based on the key by ZAWIRSKA (1994).

In order to determine the degree of injury to the surface of leaf stems, 10 onion plants were harvested from each plot. Then, three leaves were collected from the plants (the oldest leaf, a leaf of intermediate age and the youngest leaf) and a $10 \mathrm{~cm}$ long segment was excised from the centre of each leaf. The proportion of injured leaf area in each segment was estimated as a percentage.

\section{RESULTS}

Throughout the growing season, polyphagous species on the onion plants primarily consisted of two polyphagous species of thrips such as Thrips tabaci, Frankliniella intonsa (TRYвOM, 1895) and one predatory species, Aeolothrips intermedius BAGnall, 1934. The species preying on and causing damage to the onion was Thrips tabaci. Individual years differed in terms of the number of thrips caught by sweeping and collected from 10 randomly selected plants (Table 1). In 2012, the highest number of thrips caught in sweep nets was on Aeolothrips fistulosum (296 individuals/plot). The cultivars of Allium cepa most seriously infested by thrips were 'Efekt' (241 thrips/plot), 'Alonso F1' ,'Alibaba' and 'Wama' (202 thrips/plot) and the 'NOE5' breeding line (Table 2). The smallest numbers of thrips were collected from the 'NOE1' breeding line and the 'Tęcza' cultivar $(<100$ individuals / plot) (Table 2). In the second year of the study, the 'Bila' cultivar and 'NOE5' breeding line were most affected by Thrips tabaci (over 200 individuals / plot) (Table 2). The lowest numbers of $T$. tabaci were recorded on the 'Santero F1' (17 inds./plot), 'Kristine', 'Densidor', 'Tęcza' and 'Alibaba F1' (29 inds./plot) cultivars In the second year 
of the study the level of infestation of Allium fistulosum was average (121 inds./plot) (Table 2).

The dynamics of onion thrips populations are exemplified by selected species, cultivars and breeding lines, characterized by the highest and lowest levels of plant colonization by the pest (Fig. 1, 2). In 2012, the first specimens of Thrips tabaci appeared on June 17 on both tested species of the genus Allium sp., cultivars and breeding lines of A. cepa. The number of $T$. tabaci on the plants gradually increased. The population of this pest peaked in the first four days of July on the 'Efekt' cultivar (98 specimens/plot) and the 'NOE5' breeding line (64 specimens/plot); the peak on Aleothrips fistulosum occurred a week later (76 specimens/plot) (Fig. 1). In the following two weeks, these cultivars were colonized by onion thrips to a lesser extent and their abundance up to the end of August remained at the level of a few to 40 individuals per plot (Fig. 1). Conversely, in the less populated 'Tęcza' cultivar and the 'Wolska' and 'NOE1' breeding lines, the mid-June to mid-July population of thrips ranged from 10 to 32 individuals/plot; up to the end of the growing season this figure gradually decreased to single thrips per plot (Fig. 1).

The population dynamics of Thrips tabaci on the most susceptible onion cultivars in 2013 is illustrated in Fig. 2. The first specimens were collected from the breeding lines 'NOE5' and the cultivar 'Bila' (on June 19), while the 'Polanowska' cultivar was found up to two weeks later. The thrips population remained at a low level until mid-July. An increase in the number of thrips to about 30 specimens/plot took place in the final ten days of July. Renewed growth, albeit different for the cultivars described, took place in the first week of August. In this period the T. tabaci population increased from 38 specimens/plot (breeding line 'NOE5') to 83 specimens/plot (for the 'Polanowska' cultivar). In midAugust the number of thrips on the 'Polanowska' and 'Bila' cultivars decreased; only in the case of the NOE 5 breeding line was a re-growth observed, from 5 to 42 individuals/plot (Fig. 2). Conversely, in the same year, the maximum number of onion thrips on the cultivars less attractive these insects did not exceed 7 individuals per plot ('Densidor' cultivar) (Fig. 2). 
Table 1. Total number of thrips (Thysanoptera) collected from Alium fistulosum, A. roylei and A. сера in 2012 and 2013. N - number of individuals, Tt - Thrips tabaci, $F i$ - Frankliniella intonsa, Ai-Aeolothrips intermedius.

\begin{tabular}{|c|c|c|c|c|r|r|r|r|}
\hline \multirow{3}{*}{ Year } & \multicolumn{8}{|c|}{ Number of Thrips collected } \\
\cline { 2 - 9 } & \multicolumn{9}{|c|}{ by sweeping nets } & \multicolumn{4}{|c|}{ from leaves } \\
\cline { 2 - 9 } & $\boldsymbol{T} \boldsymbol{t}$ & $\boldsymbol{F i}$ & $\boldsymbol{A i}$ & $\mathbf{N}$ & $\boldsymbol{T} \boldsymbol{t}$ & $\boldsymbol{F i}$ & $\boldsymbol{A i}$ & \multicolumn{1}{c|}{$\mathbf{~}$} \\
\hline 2012 & 4120 & 6773 & 840 & 11733 & 561 & 1071 & 97 & 1729 \\
\hline 2013 & 2232 & 975 & 91 & 3298 & 34 & 27 & 8 & 69 \\
\hline
\end{tabular}

Table 2. Selected information about Thrips tabaci occurence on Alium fistulosum, A. roylei and cultivars and breeding lines of $A$. cepa collected by sweaping nets in 2012 and 2013. $\mathrm{TN}$ - number of thrips, DM - date of the maximum number of thrips, $\mathrm{MN}$ - the maximum number of thrips, * - no data.

\begin{tabular}{|l|r|c|r|r|r|r|}
\hline \multirow{2}{*}{$\begin{array}{c}\text { Species cultivar } \\
\text { breeding lines }\end{array}$} & \multicolumn{3}{|c|}{$\mathbf{2 0 1 2}$} & \multicolumn{3}{c|}{$\mathbf{2 0 1 3}$} \\
\cline { 2 - 7 } & TN & DM & MN & TN & DM & MN \\
\cline { 2 - 7 } & & & & & & \\
\hline A. fistulosum & 296 & 12.07. & 76 & 121 & 19.08. & 40 \\
\hline A. roylei & $*$ & $*$ & $*$ & 60 & 03.08. & 34 \\
\hline Alibaba & 213 & 04.07. & 51 & 29 & 03.08. & 9 \\
\hline Alonso F1 & 225 & 04.07. & 79 & 54 & 24.07. & 12 \\
\hline Billa & 121 & 27.06. & 26 & 221 & 03.08. & 66 \\
\hline Densidor & 191 & 04.07. & 63 & 25 & 18.07. & 7 \\
\hline Density & 157 & 27.06. & 37 & 41 & 31.07. & 12 \\
\hline Efekt & 241 & 04.07. & 98 & 88 & 03.08. & 46 \\
\hline Hylander F1 & 170 & 27.06. & 45 & 36 & $31.07 . / 03.08$. & 9 \\
\hline Kristine & 118 & 12.07. & 27 & 19 & 18.07. & 5 \\
\hline Kuba F1 & 165 & 17.06. & 43 & 62 & 18.07. & 17 \\
\hline Ławica & 156 & 04.07. & 50 & 99 & 03.08. & 28 \\
\hline NOE1 & 90 & 04.07. & 31 & 63 & 24.07. & 14 \\
\hline NOE2 & 172 & 12.07. & 45 & 106 & 03.08. & 31 \\
\hline NOE3 & 167 & 27.06. & 49 & 90 & 03.08. & 30 \\
\hline NOE4 & 156 & 04.07. & 56 & 159 & 03.08. & 77 \\
\hline NOE5 & 226 & 04.07. & 64 & 214 & 19.08. & 45 \\
\hline Polanowska & 162 & 27.06. & 37 & 193 & 03.08. & 83 \\
\hline Santero F1 & 183 & 12.07. & 49 & 17 & 18.07. & 3 \\
\hline Sochaczewska & 154 & 27.06. & 51 & 157 & 03.08. & 53 \\
\hline Tęcza & 98 & 27.06. & 28 & 26 & 18.07. & 7 \\
\hline Wama & 202 & 04.07. & 57 & 88 & 13.08. & 19 \\
\hline Wenta & 159 & 27.06. & 53 & 108 & 03.08. & 29 \\
\hline Wola & 184 & 04.07. & 51 & 51 & 19.08. & 15 \\
\hline Wolska & 114 & 12.07. & 25 & 105 & 03.08. & 31 \\
\hline & & & & & & \\
\hline
\end{tabular}



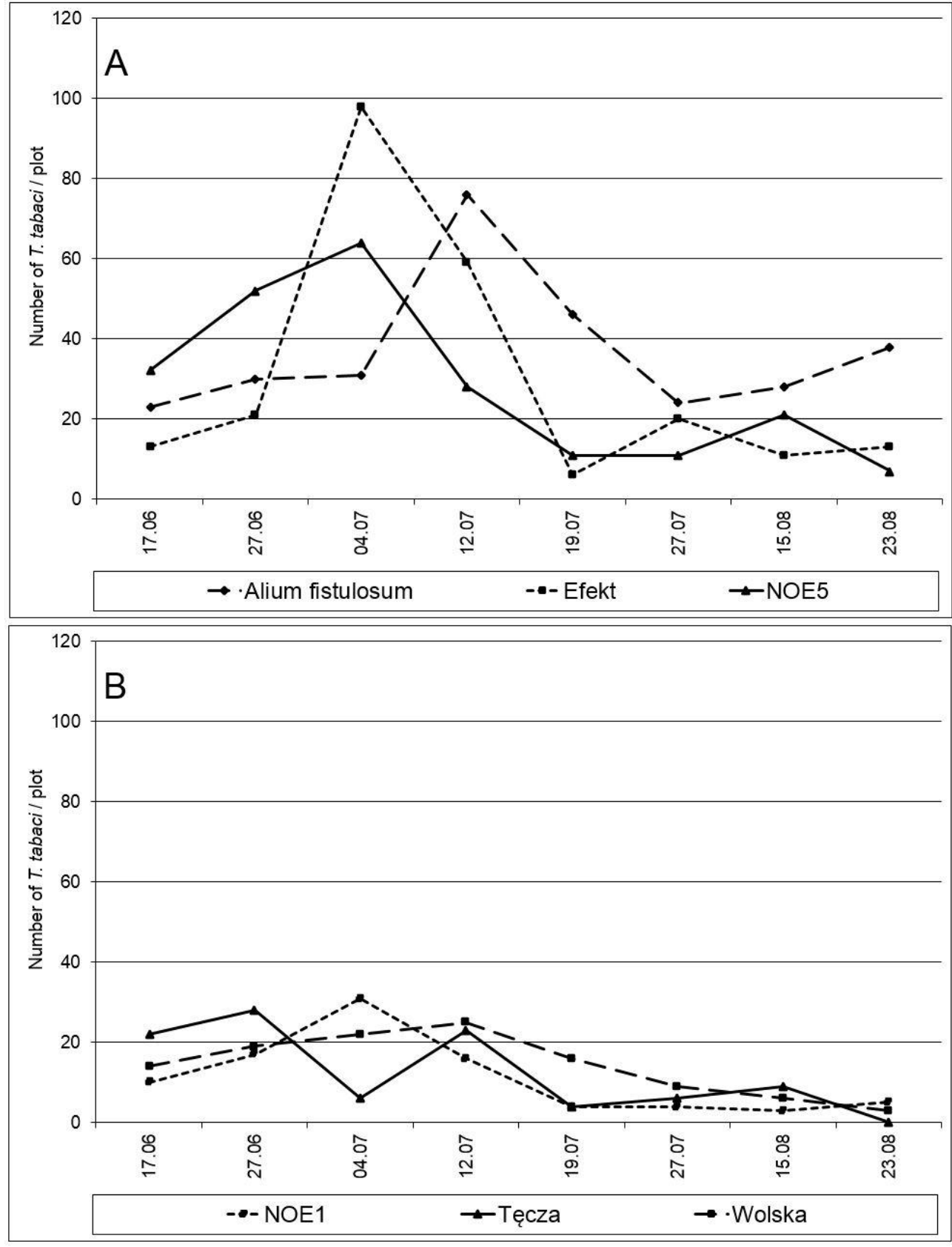

Fig. 1. The seasonal population dynamics of Thrips tabaci in 2012 at the most (A) and the least (B) varietes of onion (Alium cepa). 

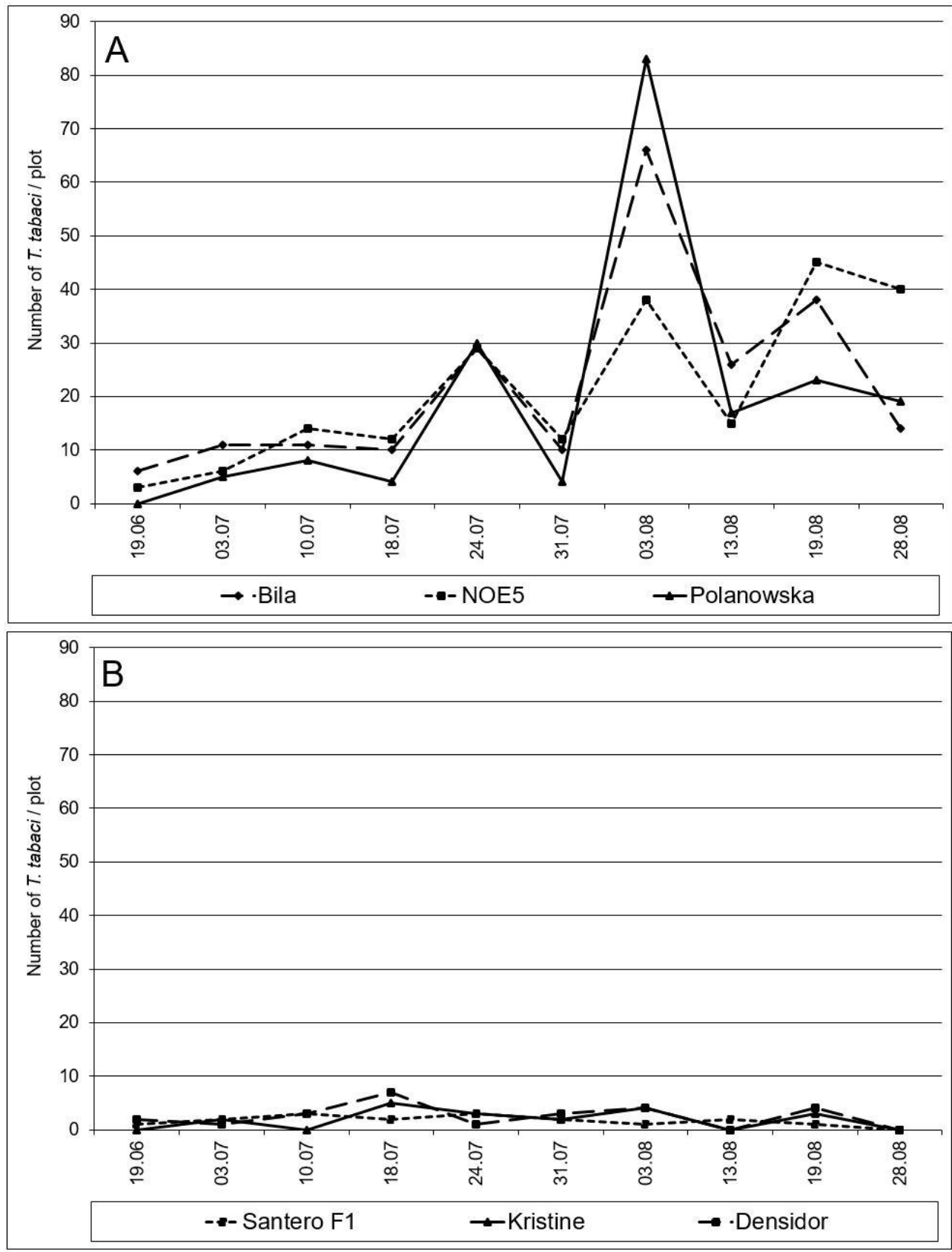

Fig. 2. The seasonal population dynamics of Thrips tabaci in 2013 at the most (A) and the least (B) varietes of onion (Alium cepa). 
Table 3. Thrips tabaci damage and number on leaves of Alium fistulosum, A. roylei and cultivars and breeding lines of A. cepa in 2012 and 2013. MN/10 - Mean number of thrips / 10 plants, DL [\%] - Damage of leaves [\%], * - no data.

\begin{tabular}{|l|c|r|r|r|}
\hline \multirow{2}{*}{$\begin{array}{c}\text { Species cultivar } \\
\text { breeding lines }\end{array}$} & MN/10 & DL [\%] & MN/10 & DL [\%] \\
\cline { 2 - 5 } & \multicolumn{2}{|c|}{$\mathbf{2 0 1 2}$} & \multicolumn{2}{|c|}{$\mathbf{2 0 1 3}$} \\
\hline A. fistulosum & 9 & 12.0 & 0 & 20.0 \\
\hline A. roylei & $*$ & $*$ & 3 & 0.0 \\
\hline Alibaba & 34 & 35.0 & 0 & 29.0 \\
\hline Alonso F1 & 37 & 49.0 & 2 & 18.0 \\
\hline Billa & 23 & 41.0 & 0 & 30.0 \\
\hline Densidor & 13 & 46.0 & 0 & 18.0 \\
\hline Density & 10 & 15.0 & 0 & 28.0 \\
\hline Efekt & 38 & 52.0 & 0 & 25.0 \\
\hline Hylander F1 & 26 & 13.0 & 2 & 28.0 \\
\hline Kristine & 23 & 45.0 & 1 & 31.0 \\
\hline Kuba F1 & 26 & 39.0 & 1 & 33.0 \\
\hline Ławica & 22 & 35.0 & 2 & 27.0 \\
\hline NOE1 & 18 & 48.0 & 2 & 37.0 \\
\hline NOE2 & 20 & 55.0 & 6 & 36.0 \\
\hline NOE3 & 31 & 45.0 & 0 & 31.0 \\
\hline NOE4 & 19 & 43.0 & 1 & 24.0 \\
\hline NOE5 & 22 & 43.0 & 1 & 27.0 \\
\hline Polanowska & 55 & 38.0 & 0 & 33.0 \\
\hline Santero F1 & 7 & 33.0 & 3 & 33.0 \\
\hline Sochaczewska & 20 & 40.0 & 0 & 32.0 \\
\hline Tęcza & 14 & 40.0 & 0 & 30.0 \\
\hline Wama & 11 & 50.0 & 5 & 24.0 \\
\hline Wenta & 16 & 41.0 & 40.0 & 26.0 \\
\hline Wola & 47 & 21.0 & & \\
\hline Wolska & 20 & & 0 & \\
\hline
\end{tabular}

These results indicate that onion cultivars differ in the degree of occupation and susceptibility to feeding by Thrips tabaci. Onion thrips cause damage to the surface of the leaves of onion chives throughout the growing season. Clearly, the breeding lines most damaged by thrips in 2012 were NOE2 and the 'Efekt', 'Wama' and 'Alonso F1' cultivars, where the degree of injury ranged from 49 to $55 \%$ (Table 3). In contrast, the smallest and similar degree of injury to stems were recorded on Allium fistulosum and the 'Hylander F1' cultivar (12-13\% damage of leaves) (Table 3). In 2013, the most seriously damaged leaf stems were observed on the 'NOE2' and 'NOE3' breeding lines, and on the 'Sochaczewska', 'Santero F1' and 'Eawica' cultivars, the extent of injury to these leaves ranging from 33 to $37 \%$ (Table 3). The degree of leaf damage on the 'Density' cultivar and 
on A. fistulosum was low - from 18 to $20 \%$ (Table 3 ). Though heavily populated during the growing season, the 'Bila' cultivar was in fact only slightly injured by Thrips tabaci (18\% of the leaf area injured) (Tables 2,3). Larger numbers of onion thrips caught in sweep nets do not always reflect extensive damage to leaf surfaces. In 2012, for example, Allium fistulosum was very badly infested with Thrips tabaci, but damage to leaf surfaces was only minor. Furthermore, feeding onion thrips caused no damage to the wild species Allium roylei, even though they were harvested from that plant (Tables 2, 3).

\section{DISCUSSION}

The results indicate that onion plants are inhabited by three species of thrips during the growing season: two herbivorous ones (Frankliniella intonsa, Thrips tabaci) and a predatory one (Aeolothrips intermedius). Frankliniella intonsa is a polyphagous, common inhabitant of the flowers of various plants, Thrips tabaci is a common, polyphagous phytophage, feeding on both the green parts and the flowers, and Aeolothrips intermedius is a predatory species (ZAWIRSKA, 1994). During research on the composition of thrips species on onion and leek, PoBożNiaK et al. (2007) and LEgutowska \& THEUNISSEN (2003) observed the frequent occurrence of Frankliniella intonsa, Aeolothrips intermedius and Thrips tabaci, as well as other species, whereas TRDAN et al. (2005) reported high numbers of Aeolothrips intermedius and Thrips tabaci on Allium cepa.

Table 4. Mean air temperature (Temp.) and rainfall (Rain) total in years 2012 and 2013. $\mathrm{M}$ - mean values.

\begin{tabular}{|c|c|c|c|c|c|c|c|c|c|c|c|c|c|c|c|c|c|c|c|c|c|}
\hline \multirow{3}{*}{$\begin{array}{l}\text { Weather } \\
\text { factor }\end{array}$} & \multirow{3}{*}{$\underset{\nu}{ \pm}$} & \multicolumn{20}{|c|}{ Month and ten days } \\
\hline & & \multicolumn{4}{|c|}{ April } & \multicolumn{4}{|c|}{ May } & \multicolumn{4}{|c|}{ June } & \multicolumn{4}{|c|}{ July } & \multicolumn{4}{|c|}{ August } \\
\hline & & $\tau$ & v & $m$ & $\Sigma$ & - & v & $m$ & $\Sigma$ & - & N & $m$ & $\Sigma$ & - & $\mathrm{N}$ & $m$ & $\Sigma$ & - & N & $\infty$ & $\sum$ \\
\hline Temp. $\left[{ }^{\circ} \mathrm{C}\right]$ & $N$ & n? & $\stackrel{\circ}{0}$ & $\stackrel{\vartheta}{ \pm}$ & $\vec{\ominus}$ & $\overrightarrow{6}$ & $\stackrel{\jmath}{\underline{\jmath}}$ & $\stackrel{\infty}{\Xi}$ & $\begin{array}{l}0 \\
i \\
n\end{array}$ & $\begin{array}{l} \\
\ddot{n}\end{array}$ & $\begin{array}{l}m \\
\infty \\
\infty\end{array}$ & $\begin{array}{l}\circ \\
\stackrel{2}{-}\end{array}$ & $\stackrel{?}{\simeq}$ & $\begin{array}{l}\stackrel{0}{+} \\
\stackrel{+}{N}\end{array}$ & $\stackrel{\beth}{\check{I}}$ & $\begin{array}{l}0 \\
\stackrel{0}{ }\end{array}$ & $\stackrel{+}{\dot{d}}$ & $\stackrel{0}{\dot{\lambda}}$ & $\begin{array}{l}\infty \\
\ddot{n}\end{array}$ & $\underline{\partial}$ & $\stackrel{\vartheta}{\infty}$ \\
\hline Rain [mm] & $\bar{N}$ & $\begin{array}{l}\infty \\
\stackrel{0}{0}\end{array}$ & $\stackrel{\infty}{\infty}$ & $\begin{array}{l}\text { to } \\
0 \\
0\end{array}$ & $\overbrace{0}^{\circ}$ & $\stackrel{\circ}{\circ}$ & 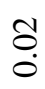 & $\ddot{0}$ & $\begin{array}{l}\tilde{0} \\
0 \\
0\end{array}$ & 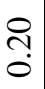 & ָิ & $\begin{array}{l}0 \\
\stackrel{0}{0}\end{array}$ & $\stackrel{n}{\stackrel{0}{0}}$ & $\stackrel{0}{0}$ & $\stackrel{\circ}{0}$ & $\begin{array}{l}\stackrel{0}{0} \\
0\end{array}$ & $\stackrel{0}{0}$ & $\begin{array}{l}\stackrel{0}{0} \\
0\end{array}$ & $\begin{array}{l}\infty \\
0 \\
0 \\
0\end{array}$ & $\begin{array}{l}1 \\
0 \\
0\end{array}$ & $\stackrel{0}{\circ}$ \\
\hline Temp. $\left[{ }^{\circ} \mathrm{C}\right]$ & ल & $m$ & $\dot{0}$ & $\stackrel{\widehat{I}}{\mathrm{I}}$ & $\stackrel{\circ}{\circ}$ & $\vec{n}$ & $\begin{array}{l}\infty \\
\dot{\Xi}\end{array}$ & $\vec{m}$ & $\stackrel{?}{ \pm}$ & $\begin{array}{l}0 \\
\dot{0} \\
-\end{array}$ & $\stackrel{\sim}{\vec{\lambda}}$ & $\begin{array}{l}\stackrel{t}{\bullet} \\
\stackrel{\bullet}{0}\end{array}$ & $\stackrel{\text { Nִ }}{\infty}$ & $\stackrel{\infty}{\stackrel{\infty}{I}}$ & ?2 & $\begin{array}{l}0 \\
\text { ì }\end{array}$ & $\stackrel{0}{8}$ & $\stackrel{\infty}{\stackrel{9}{9}}$ & $\stackrel{?}{\stackrel{2}{=}}$ & $\mid \begin{array}{l}0 \\
\dot{I}\end{array}$ & $\stackrel{?}{=}$ \\
\hline Rain [mm] & $\bar{N}$ & $\stackrel{n}{0}$ & o & $\begin{array}{l}\infty \\
\stackrel{0}{0} \\
0\end{array}$ & ? & $\begin{array}{l}\text { I } \\
0\end{array}$ & $\begin{array}{l}0 \\
0 \\
0\end{array}$ & ?n. & $\begin{array}{l} \pm \\
0\end{array}$ & $\begin{array}{l}\tilde{\imath} \\
\tilde{0}\end{array}$ & $\stackrel{\overbrace{}}{0}$ & $\begin{array}{l}8 \\
\stackrel{0}{0}\end{array}$ & $\stackrel{\Xi}{0}$ & $\overline{0}$ & $\stackrel{8}{8}$ & $\stackrel{2}{0}$ & $\stackrel{2}{0}$ & $\begin{array}{l}\infty \\
\stackrel{0}{0}\end{array}$ & 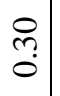 & $\begin{array}{l}0 \\
0 \\
0\end{array}$ & $\stackrel{8}{\circ}$ \\
\hline
\end{tabular}


The number of specimens collected differed in 2012-2013. The much smaller numbers of thrips observed in the second year of the study were probably a result of the unfavourable weather conditions, which could have affected the development of populations of onion thrips. In comparison to the May and June of the previous year, these months were characterized by excessive rainfall, which prevented further plant growth (Table 4). Liu (2004) and SelvaraJ \& Adiroubane (2012) reported that cold and rainy weather significantly reduces the growth of thrips populations. Furthermore, MACINTYREALLEN et al. (2005) state that the population dynamics of onion thrips also depend on the weather conditions prevailing during and preceding the population survey.

Of the species found on onion, probably only Thrips tabaci caused damage to this plant. During both years of the study, the first $T$. tabaci individuals were observed on the plots of all the onion cultivars between early and mid June. In 2012, the T. tabaci population reached its first peak on 4 and 12 July, whereas in 2013 it occurred on 3 August. Moreover, the study by POBOŻNIAK et al. (2007) in southern Poland showed that onions grown from seed show the largest increase in the number of $T$. tabaci recorded in the latter two thirds of August. NAWROCKA (2003) found that in central Poland onion thrips populations on onions reach their maximum in late July and early August.

There were sometimes very large differences between the number of thrips feeding on the leaves of the various species, cultivars and breeding lines.

KENDALL \& CAPINERA (1987) found that the presence of 10 Thrips tabaci individuals on a plant reduces the onion yield by 2-3\%. FounIER et al. (1995) determined the threshold pest hazard level as 0.9-2.2 individuals per leaf. RUEDA et al. (2007) indicated that farmers should apply an insecticide when infestation reaches levels of between 0.5 and 1.6 thrips per leaf. Our results indicate that in 2012 some of the cultivars tested were infested well above the harmfulness threshold. These included the 'Polanowska' and 'Wola' cultivars (very commonly grown in Poland), on which 55 and 47 specimens of $T$. tabaci / 10 plants were found. The 'Alibaba', 'Alonso F1', 'Efekt' and 'NOE3' cultivars were also close to the harmfulness threshold; over 30 individuals / 10 plants were collected from these plants (Table 3). Therefore, it is recommended that these cultivars should be cultivated with great care and they that should be subjected to further tests.

The susceptibility of different cultivars to colonization and thrips grazing is often described in the literature (COUDRIET et al. 1979, DIAZ-MONTANO et al. 2010, TRDAN et al. 2008). While finding the same differences in resistance between the tested cultivars is relatively easy, determining the causes of this phenomenon can be very difficult. Various studies on the resistance of onions to Thrips tabaci have also been conducted, and resistance has been linked to leaf structure and colour (FAIL et al. 2013, HUDAK \& PÉNZES 2004, DiAZ-MONTANO et al. 2010, 2012, TRDAN et al. 2004). Resistance can be affected by factors such as the sugar and nitrogen levels in the leaves (ANANTHAKRISHNAN \& 


\section{GOPICHANDRAN 1993, PANDA \& KUSH 1995).}

The results presented here may provide a basis for further research to identify onion varieties recommended for cultivation in southern Poland. Planned future studies of morphological and biochemical variations (in terms of their different attractiveness to Thrips tabaci) may suggest possible lines of action for the cultivation of pest-resistant onions.

\section{REFERENCES}

Ananthakrishnan T.N., Gopichandran R. 1993. Chemical Ecology in Thrips - Host Plant Interactions. International Science Publisher, New York.

Coudriet D.L., Kishaba A.N., Mccreight J.D, Bohn G.W. 1979. Varietal resistance in onions to thrips. Journal of Economic Entomology 72(5): 614-615.

CSoP [Central Statistical Office of Poland / Główny Urząd Statystyczny] 2012. Internet: http://stat.gov.pl

Diaz-Montano J., Fuchs M., Nault B.A, Fail J., Shelton A.M. 2010. Onion thrips (Thysanoptera: Thripidae): a global pest of increasing concern in onion. Journal of Economic Entomology 104(1): $1-13$.

Diaz-Montano J., Fail J., Deutschlander M., Nault. B.A, Shelton A.M. 2012. Characterization of resistance, evaluation of the attractiveness of plant odors, and effect of leaf color on different onion cultivars to onion thrips (Thysanoptera: Thripidae). Journal of Economic Entomology 105(2): 632-641.

Fail J., Deutschlander M., Shelton A.M. 2013. Antixenotic Resistance of Cabbage to Onion Thrips (Thysanoptera: Thripidae). I. Light Reflectance. Journal of Economic Entomology 106(6): 2602-2612.

FourniER F., BoIvin G., StewART R.K. 1995. Effect of Thrips tabaci (Thysanoptera: Thripidae) on yellow onion yields and economic thresholds for its management. Journal of Economic Entomology 88(5): 1401-1407.

GOMBAČ P., TRDAN S. 2014. The efficacy of intercropping with birdsfoot trefoil and summer savoury in reducing damage inflicted by onion thrips (Thrips tabaci, Thysanoptera, Thripidae) on four leek cultivars. Journal of Plant Diseases and Protection 121(3): 117-124.

HudÁK K., PÉnZes B. 2004. Factors influencing the population of the onion thrips on onion. Acta Phytopathologica et Entomologica Hungarica 39(1-3): 193-197.

Kendall D.M., Capinera J.L. 1987. Susceptibility of onion growth stages to onion thrips (Thysanoptera: Thripidae) damage and mechanical defoliation. Environmental Entomology 16(4): $859-863$.

Kendall D.M, CAPINERA J.L. 1990. Geographic and temporal variation in the sex ratio of onion thrips. Southwest Entomologist 15(1): 80-88.

Kogan M. 1975. Plant resistance in pest management. [in:] R.L. MetCALF, W.H. LuCKMANN (eds.) Introduction to insect pest Management. John Wiley \& Sons, New York, USA, 103-146. 
Legutowska H., Theunissen J. 2003. Thrips species in leeks and their undersown intercrops. IOBC/WPRS Bulletin 26(3): 177-182.

LEWIS T. 1973. Thrips: their biology, ecology and economic important. Academic Press, LondonNew York.

LEWIS T. 1997. Pest thrips in perspective. [in:] T. LEWIS (ed.). Thrips as crop pests. CAB International, New York, 1-13.

LEVY D., KEDAR N. 1970. Effect of Ethrel on growth and bulb initiation in onion. Horticultural Science 5: 80-82.

LIU T.X. 2004: Seasonal population dynamics, life stage composition of Thrips tabaci (Thysanoptera: Thripidae), and predaceous natural enemies on onions in south Texas. Southwestern Entomologist 29(2): 127-135.

LIU T.X., SPARKS A.N. 2003. Injury and distribution of onion thrips (Thysanoptera: Thripidae) in red cabbage heads. Southwestern Entomologist 28(1): 77-79.

Macintyre-Allen J.K., Scott-Dupree C.D., Tolman J.H., Harris C.R. 2005. Evaluation of Sampling Methodology for Determining the Population Dynamics of Onion Thrips (Thysanoptera: Thripidae) in Ontario Onion Fields. Journal of Economic Entomology 98(6): 2272-2281.

Maniania N.K., Sithanantham S., Ekesi S., Ampong-Nyarko K., Baumgartner J., Lohr B., MатокA C.M. 2003. A field trial of the entomogenous fungus Metarhizium anisopliae for control of onion thrips, Thrips tabaci. Crop Protection 22(3): 553-559.

MetCALF R.L., LuCKMANN W.H. 1975. Introduction to insect pest management. John Wiley \& Sons, New York, USA.

NAWROCKA B. 2003: Economic importance and the control method of Thrips tabaci LiND. on onion. Integrated Control in Field Vegetable Crops IOBC Bulletin 26(3): 321-324.

PANDA N., Khush G.A. 1995. Host plant resistance to insects. CAB International, Wallingford.

PARRELla M.P., LEWIS T. 1997. Integrated pest management (IPM) in field crops. [in:] T. LEWIS (ed.). Thrips as crop pests. CAB International, New York, 595-614.

PÉnZes B., SzANi Sz., FERENCZY A. 1996. Damage of Thrips tabaci on cabbage varieties in Hungary. Folia Entomologica Hungarica 47(Suppl.): 127-137.

Pobożniak M., Koschier E. 2013. Effects of pea (Pisum sativum L.) cultivars on Thrips tabaci LINDEMAN preference and performance. The Journal of Agricultural Science 152(6): 885-893.

PobożNiak M., Palacz A., Rataj A. 2007. The occurrence and species composition of thrips (Thysanoptera) on onion. Communications in agricultural and applied biological sciences 72(3): 487-493.

RASPUDiĆ E., Ivezić M. 1999. Host plants and distribution of thrips Thrips tabaci LindEMAN, 1888 (Thysanoptera, Thripidae) in Croatia. Entomologia Croatica 4(1-2): 57-62.

Rueda A., Badenes-Perez F., Shelton A.M. 2007. Developing economic thresholds for onion thrips in Honduras. Crop protection 28(8): 1099-1107. 
Selvaraj S., Adiroubane D. 2012. Influence of weather parameters on the incidence of thrips, Thrips tabaci LINDEMAN in cotton. Journal of Cotton Research and Development 26(2): 234-237.

SMITH M.C. 2005. Plant resistance to arthropods. Springer, The Netherlands.

Theunissen J., Schelling G. 1998. Infestation of leek by Thrips tabaci as related to spatial and temporal patterns of undersowing. Biocontrol 43(1): 107-119.

TRDAN S. 2003. The occurrence of thrips species from the Terebrantia suborder on cultivated plants in Slovenia. Zbornik Biotehniške fakultete Univerze v Ljubljani, Kmetijstvo, Agricultural issue 81(1): $57-64$.

Trdan S., AnAJus L., RasPudič E. 2005. Distribution of Aeolothrips intermedius BAgnalL (Thysanoptera: Aeolothripidae) and its potential prey Thysanoptera species on different cultivated host plants. Journal of Pest Science 78(4): 217-226.

Trdan S., Anajus L., Vovk I., Marelanc M., Simonowska B., Jerman I., Vigrih R., Vidrih M., ŽNIDARČIČ D. 2008. Which plant compounds influence the natural resistance of cabbage against onion thrips (Thrips tabaci LiNDEMAN)? Acta Phytopathologica et Entomologica Hungarica 43(2): 385-395.

TRDAN S., ŽNidARČIČ D., Zlatič E., JERMAN J. 2004. Correlation between epicuticular wax content in the leaves of early white cabbage (Brassica oleracea L. var. capitata) and damage caused by Thrips tabaci LindEMAN (Thysanoptera: Thripidae). Acta Phytopathologica et Entomologica Hungarica 39(1-3): 173-185.

Waiganjo M., Mueke J.M., Gitonga L.M. 2008. Susceptible onion growth stages for selective and economic protection from onion thrips infestation. [in:] R.K. PRANGE, S.D. BISHOP (eds.) Proceedings, Symposium: Sustainability through integrated and organic horticulture. International Symposium of the International Society for Horticultural Science (ISHS), 13-19 August 2006, Seoul, Korea. Publication Acta Horticulturae. 767. International Society for Horticultural Science, Leuven, Belgium, 193-200.

ZawiRsKa I. 1994. Thrips (Thysanoptera). [in:] M.W. KozŁowsKi, J. BoczeK (eds.). Diagnostics of plant pests and their natural enemies. SGGW, Warszawa, 145-174. (in Polish)

Received: 25 June 2015

Accepted: 21 September 2015 